\title{
Factors Affecting Effective Dissemination of Peace and Order Ordinances to Punong Barangays in Maria Aurora, Philippines
}

\author{
Freyanne A. Redoble \\ Office of the Sangguniang Bayan, \\ Local Government Unit of Maria Aurora, Aurora Province, Philippines \\ E-mail: fayee_yaf@yahoo.com
}

Vilma B. Ramos (Corresponding author)

Department of Public Administration

Nueva Ecija University of Science and Technology

Cabanatuan City 3100, Philippines

E-mail: vilma_ramos05@yahoo.com

\begin{abstract}
Amerjaphil Louie A. Vidal
Municipal Social Welfare and Development Office,

Local Government Unit of Llanera, Nueva Ecija, Philippines

E-mail: april.vidal@gmail.com
\end{abstract}

Elsie Valdes

Municipal Agriculture Office

Local Government of Aliaga, Nueva Ecija, Philippines

E-mail: elsievaldez_14@yahoo.com

Received: Oct. 22, 2018 Accepted: Nov. 19, 2018 Online published: Dec. 18, 2018

doi:10.5296/jpag.v8i4.14065 URL: https://doi.org/10.5296/jpag.v8i4.14065 


\section{Abstract}

The study measured the factors affecting effective dissemination of peace and order ordinances to punong barangays in the Municipality of Maria Aurora, Aurora Province, Philippines. The study used predesigned survey questionnaires and key informants in the gathering of data. The questionnaire distribution was based on purposive sampling. The participants are thirty-four (34) punong barangays. The barangay is the smallest political unit in the Philippines. The data gathered are treated with frequency distribution and weighted mean. The factors of dissemination are: a) socio-demographic characteristics of respondents, b) information sources, c) strategies and channels of communication are measured. In general, participants' level of interest towards new legislation is positive. However, a slight divergence is noticed in the case of upland barangays as they manifested little awareness on the existing peace and order ordinances. Thus, it is recommended that effective dissemination strategies be adopted and information materials be developed to improve dissemination of new ordinances. The use of Information and Communication Technologies (ICTs) in information dissemination is highly recommended.

Keywords: dissemination, peace and order, ordinance, punong barangays, Maria Aurora

\section{Introduction}

The structure and organizational set up of the Philippine political system is characterized by democratic and republican practices (Gabriel, 2017). In the local level, the system of check and balance and separation of powers are observed. The powers and functions of the three branches of government to wit; executive, legislative and judicial are simultaneously exercise by three different departments. For instance, the power to enact, repeal and amend laws is exercised by the local legislative body mandated by law to pass upon ordinances and resolutions applicable within its territorial jurisdiction. The term ordinance is formally defined as "a rule established by authority, a permanent rule of action, a law, or a statute. It is a local law of a municipal corporation. It is duly enacted by the proper authorities, prescribing general, uniform, and permanent rules of conduct relating to the corporate affairs of the municipality" (Martin, 2005). Numerous ordinances are enacted by local governments. However, in practice, there are questions as to their implementation, proper dissemination and interest of the local leaders.

The manner on how to disseminate information regarding local ordinances is provided in the Republic Act No. 7160 or the Local Government Code of 1991, to wit; "Ordinance or Resolution shall be posted in the bulletin board at the entrance of the provincial capital and the city, municipal, or barangay hall, as the case may be, and in at least two (2) conspicuous places in the local government unit concerned not later than five (5) days after approval thereof." It is also mandated that the ordinance must be published in newspapers (Section $59[\mathrm{c}])$.

Making known to the public new ordinances and resolutions is very important. Municipalities can take steps to prevent controversy arising from non dissemination of new ordinances or resolution by posting to social media or running awareness on public access channels (Walker, 
2017). It is a well settled rule in Philippine jurisdiction that "ignorantia legis neminem excusat (ignorance of the law excuses no one) from compliance there with" (Black, 1910). This principle in law holds that regardless of the knowledge of a person on the existence of the law, he is bound to observe it. And in case of violation, ignorance is not a legal defense to avoid liability.

The term barangay refers to "the basic political unit in the Philippines that implements policies of local and national governments and performs the role of primary planning and implementing a unit of government policies, plans, programs, projects, and activities in the community," (Caldo, 2015). The Punong Barangay, as chief executive, is the one enforcing all laws and ordinances which applicable within the barangay and intended to maintain public order. Punong Barangays may also assist the city or municipal mayor and the sanggunian (local legislative body) members in the performance of their duties and functions (RA 7160, 1992). Executive Order Number 366 mandated that every barangay must create Barangay Peace and Order Committee (BPOC) that acts as implementing arm of the City/Municipal Peace and Order Council at the barangay level. (Capeless, n.d.) also maintained that crime prevention is everyone's responsibility, not just law enforcement. They should actively engage in activities for good governance as well as implement policies and programs that run parallel to local government efforts at improving the lives of people. Accordingly, barangay officials are expected to be more aware of the peace and order ordinances that are intended for implementation.

The importance of disseminating new ordinances can be gleaned from the body of knowledge made in the topic. In a study conducted at Bakun, Benguet, Gatab (2008) identified several factors affecting effective dissemination of ordinance, namely: lack of mass media communication channels, lack of transportation and accessibility from the municipal hall to the barangays because of the geographical location of the barangays and poor road conditions, lack of interest and understanding, and lack of budget. Meanwhile, Catedrilla, Serofia, Espectato \& Jimenez (2010) identified "socio-demographic characteristics of the target stakeholders such as the type of Local Government Unit (LGU), the age, educational attainment, experience, and distance of residence from the barangay hall are factors to consider in the dissemination of information regarding ordinances. Consequently, it is imperative that information delivery must be served by the government at the best possible means. Studies such as conducted by Momodu (2002) (as cited in Shaifuddin, Ahmad \& Haliza Wan Mokhtar, 2011) showed that rural populations in Nigeria have lack of access to information, which is a vital necessity for their development process.

Recently, controversy affecting information dissemination of the ordinances made by Sangguniang Bayan of Maria Aurora surfaced. It was observed that many violations are committed due to lack of awareness on the legislations. This made the researchers to believe that there is a need to undertake study on the matter. An assessment of the strategies and methods employed in the dissemination of peace and order ordinances to punong barangays is therefore necessary because the barangay government has a strong influence on the grassroots level. The level of awareness of punong barangays about these ordinances also needs evaluation. The outcome of this assessment may serve as basis for the development 


\section{Macrothink}

Journal of Public Administration and Governance

ISSN 2161-7104

2018, Vol. 8, No. 4

of effective and efficient strategies for the dissemination of ordinances that can keep up with evolving technology suitable to every sector of the community.

The general objective of the study is to assess the factors affecting the effective dissemination of the peace and order ordinances to punong barangays in the Municipality of Maria Aurora, Aurora Province. Specifically, the study tried to achieve the following objectives:

a) To identify critical dissemination factors affecting punong barangays awareness of the peace and order ordinances;

b) To determine the awareness of punong barangays regarding peace and order ordinances;

c) To measure respondents interest on local ordinances;

d) To give possible recommendations to establish effective dissemination of ordinances.

\subsection{Theoretical Framework}

The study was anchored on the Social Systems Theory. A social system is a complex set of human relationships interacting in many ways (Newstrom, 2011). Systems theory focuses on the interactions and on the relationships between parts to understand an entity's organization, functioning, and outcomes (Mele, Pels \& Polese, 2010). The municipality consists of several smaller social institutions like department, committees and employees' association which are always interacting and interdependent. The barangay, as a subdivision of a municipality, also requires proper coordination, role clarity, and healthy relationship with the municipal government to carry out and enforce laws effectively. Newstrom (2011) stated that "social systems are, therefore, open systems that interact with their surroundings. Consequently, members of a system should be aware of the nature of their environments and their impact on other members both within and outside their social system."

\section{Methodology}

\subsection{Study Locale}

The study was conducted in Maria Aurora, a second-class municipality which is more or less 110 kilometers from Cabanatuan City. It forms part of the boundary of Nueva Ecija and Nueva Vizcaya. The town is accessible through the following entry points: San Luis-Maria Aurora, Castaneda-Pantabangan Road, and Baler-Bongabon Road. It has a total land area of 42,629 hectares (Comprehensive Land Use Plan, 2017) and a population of 40,734 as of 2015 (Philippine Statistics Authority, 2016). It consists of 23 lowland barangays and 14 upland barangays (CLUP, 2017). The municipality has enacted five (5) ordinances relating to peace and order in the year 2017. 


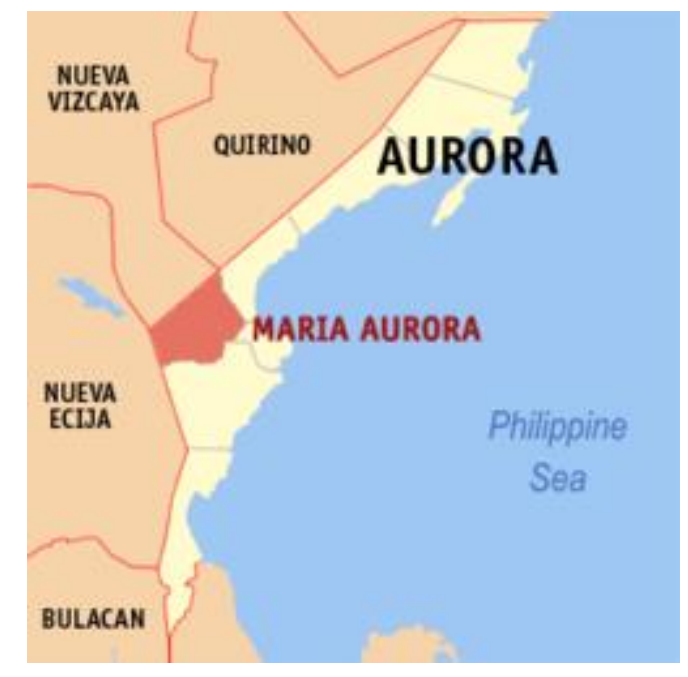

Figure 1. Map of Maria Aurora, Aurora (https://en.wikipedia.org/wiki/Maria_Aurora,_Aurora)

\subsection{Respondents}

There are forty (40) barangays in the Municipality of Maria Aurora with forty (40) respondent-punong barangays. The researcher used purposive sampling and survey questionnaires were used to gather data. The questionnaires were distributed to the punong barangays during the conduct of the Liga ng Mga Barangay First Quarterly Meeting held last March 15, 2018. Only thirty-four (34) questionnaires were retrieved by the researcher because the six other punong barangays were not in attendance during the meeting.

\subsection{Instruments}

Both primary and secondary data were used in meeting the objectives of the study. Primary information gathered included the socio-demographic profile of the respondent-punong barangay (i.e. land classification, age, gender, and educational attainment) and dissemination process factors such as their sources of information on peace and order ordinances (e.g. posted copies of ordinances, social media, LGU personnel etc.), the ordinance dissemination strategies they were exposed to, the forms or types of communication materials on peace and order ordinances they received, and their awareness on certain peace and order ordinances. Focused group discussions with the Sangguniang Bayan secretariat were employed to validate answers gathered from the respondents. Secondary data was obtained through reading materials. Likert scale was used to gauge the level of awareness of punong barangays on peace and order ordinances. The scaling provided are as follows: 3.50-4.00 - Highly aware, 2.50-3.49 - Aware, 1.50-2.49 - Less aware, 1.00-1.49 - Not aware. While as to the measurement of their level of interest towards the information, the scaling used are as follows to wit: 4.21-5.00 - Very Interested, 3.41-4.20 - Interested, 2.61-3.40 - Moderately Interested, 1.81-2.60 - Somewhat Interested, and 1.00-1.80 - Not Interested At All.

\subsection{Data Analysis}

Descriptive method was used in the study. The respondent-punong barangays were described 
using frequency distribution following some characteristics: name, age, gender, and educational attainment. This data comprised the demographic profile of the respondents. The level of awareness of the respondents was assessed using the weighted mean.

\section{Results and Discussion}

\subsection{Critical Factors in the Dissemination of Ordinances}

\subsubsection{Respondent's Profile}

For the effective dissemination of information and the correspondingly high levels of awareness, an understanding of the target audience is necessary. It is because a fundamental principle and requirement for effective communication are for the communication source to know his or her receiver or audience (Catedrilla et al., 2010). According to Rogers (1983), early adopters of technology are those who are better educated and of higher social status.

Table 1. Breakdown of Respondents as to Gender

\begin{tabular}{l|c|c}
\hline \multicolumn{1}{c|}{ Gender } & f & Percentage (\%) \\
\hline Male & 27 & 79.41 \\
\hline Female & 7 & 20.59 \\
\hline Total & 34 & 100 \\
\hline
\end{tabular}

The data in Table 1 presents that majority of the respondents are male (79.41\%). Several studies and academics reflect men's dominance in the political arena and has been one of the major struggles that dissuade women from joining the political circle (Opyd, 2014; Inter-Parliamentary Union [IPU], 1999; United Nations International Children's Emergency Fund [Unicef], 2007; Mediocre, 2011).

Table 2. Breakdown of Respondents as to Age

\begin{tabular}{l|c|c}
\hline \multicolumn{1}{c|}{ Age Bracket } & f & Percentage (\%) \\
\hline $18-59$ & 27 & 79.41 \\
\hline 60 -above & 7 & 20.59 \\
\hline Total & 34 & 100 \\
\hline
\end{tabular}

Majority of the punong barangays $(79.41 \%)$ in the municipality are at their middle age from 18 to 59 years of age. It is normal because candidates for the position of Punong Barangay must be at least eighteen (18) years of age on election day (Republic Act No. 6644, 1987). Moreover, these age brackets are in their prime and ultimately more productive.

Table 3. Breakdown of Respondents as to Education

\begin{tabular}{l|c|c}
\hline \multicolumn{1}{c|}{ Education } & $\mathrm{f}$ & Percentage $(\%)$ \\
\hline Elementary & 0 & 0 \\
\hline High School & 12 & 35.29 \\
\hline Vocational & 0 & 0 \\
\hline College & 22 & 64.71 \\
\hline Post Graduate & 0 & 0 \\
\hline Total & 34 & 100 \\
\hline
\end{tabular}


The study shows that most of the respondents have either finished high school $(35.29 \%)$ or have attended/graduated college (64.71\%). It only shows that all are educated. This supports the assessment that education increases political participation (Converse, 1972), political interest, and support for democratic institutions (Croke, Grossman, Larreguy \& Marshall, 2014). This is because people now have increased political awareness and critical capability to enter in the political arena.

Table 4. Barangay Land Classification of Respondents

\begin{tabular}{l|c|c}
\hline \multicolumn{1}{c|}{ Land Classification } & $\mathrm{f}$ & Percentage $(\%)$ \\
\hline Lowland & 23 & 67.65 \\
\hline Upland & 11 & 32.35 \\
\hline Total & 34 & 100 \\
\hline
\end{tabular}

Majority of the respondents $(67.65 \%)$ are residing in lowland barangays and have accessible transportation to the town hall thus having easy access to information. Accessibility to information is more prevalent in an urbanized community as the residents could easily mingle with one another. The topographical settings of the barangays in the municipality are so varied that some barangays could be isolated for several days during typhoons and heavy rains. "The characteristics of being rural, especially those who lived in the underserved areas often make it hard for them to access information and translate that information into useful knowledge," as provided by Shaifuddin et al. (2011).

\subsubsection{Dissemination Factors}

Information Sources. Based on studies conducted on information dissemination by the National Center for the Dissemination of Disability Research [NCDDR] (1996) (as cited in Catedrilla et al., 2010), information source characteristics also influence the attitudes of the target audience towards any kind of information being disseminated. Issues in effective dissemination and utilization that concern the information source include perceived competence, the credibility of experience and motive, sensitivity to users' interests, relationships with other sources trusted by the target users of information, and orientation towards knowledge dissemination and the use of knowledge.

The respondents gave different responses regarding who were the sources of their information about the ordinances dealing with peace and order. The data in Table 5 shows that majority of the respondents (94.12\%) replied with Sangguniang Bayan Office as their primary source of information thru postings of ordinances to conspicuous places and furnishing copies to all concerned. The results also reveal that Non-Government Organizations (NGOs)/Civil Society Organizations (CSOs) (11.76\%) and the academic institutions (2.94\%) were not their usual source of information.

Strategies and Methods to be Employed. The challenge arises on how to effectively disseminate information to target populations, i.e., seeking the most plausible means of reaching individuals based on their preferred method of informational delivery.

As regards strategies, Table 5 also indicates that Training and Seminar (41.18\%) and General 
Assembly (47.06\%) have a very minimal impact. This is because attendees in Training and Seminar do not give proper attention during such instances (personal observation).

Selection of Communication Channels. Based on previous studies, according to Catedrilla et al. (2010), different types of communication channels may have different effects on the awareness levels and behavior of target audiences. Shaifuddin et al. (2011) established that for people living in underserved areas, it is crucial to have access to information in printed or online materials. However, the study conducted by Catedrilla (2000) to some fisher folk of Batan Bay, Aklan, suggested that the communication materials could still be improved by 1) using more attractive colors, 2) including more new ideas, 3) making them more readable and comprehensible, and 4) using video instead of the printed format.

Concerning the medium of communicating ordinances, Radio Broadcast took the sizable slice with $58.82 \%$. It is because barangays that are far from the town proper has limited network coverage and television signal that's why they are highly dependent on radios to gain information. There is also an ample number of radio networks operating within the province. Also, in 2015, the Sangguniang Bayan passed Municipal Ordinance No. 20 series 2015 regarding the establishment of a public information system through the airing of programs, projects and activities of the LGU on a radio program including new statutes enacted to be broadcast all around the province and nearby provinces. Flyers/posters/brochures $(32.35 \%)$ have slightly significant roles. The respondents suggested increasing dissemination of info-graphic materials. The Internet (Social Media/Websites) (23.53\%) is not widely used because of unstable or dead network access. The Sangguniang Bayan Secretary insisted in the interview that their office continually updates the public regarding the activities of the Sangguniang Bayan as well as notices of public consultations on their Facebook page. It has been noted that no one answered for a newspaper $(0 \%)$ as their information source since there is no newspaper of general circulation in the province where the ordinance should be published.

Table 5. Factors Affecting Dissemination of Local Ordinance

\begin{tabular}{l|c|c}
\hline \multicolumn{1}{c|}{ Dissemination Factors } & $\mathrm{f}$ & Percentage (\%) \\
\hline Information Sources & & \\
\hline Sangguniang Bayan Office (Post ordinances) & 32 & 94.12 \\
\hline LGU Personnel & 10 & 29.41 \\
\hline NGOs/CSOs & 4 & 11.76 \\
\hline Academe & 1 & 2.94 \\
\hline National Government Agencies (PNP/DILG) & 6 & 17.65 \\
\hline Strategies & & \\
\hline Training/seminar & 14 & 41.18 \\
\hline General assembly/meetings & 16 & 47.06 \\
\hline Communication channels & & \\
\hline Flyers/Posters/Brochures & 11 & 32.35 \\
\hline Internet (social media/websites) & 8 & 23.53 \\
\hline Radio broadcast & 20 & 58.82 \\
\hline Newspaper & 0 & 0 \\
\hline
\end{tabular}




\subsubsection{Level of Interest of Punong Barangays on Ordinances}

The respondents' interest on local ordinance is also a factor in measuring the effectiveness of dissemination.

Table 6. Level of Interest of Punong Barangays on Ordinances

\begin{tabular}{l|c|c|c}
\hline Level of Interest & WM & VI & RANK \\
\hline $\begin{array}{l}\text { Attendance to Public } \\
\text { Hearings/Consultations. }\end{array}$ & 3.91 & Interested & 3 \\
\hline $\begin{array}{l}\text { Reads posted ordinances and } \\
\text { resolutions at the bulletin boards } \\
\text { and other conspicuous places }\end{array}$ & 4.29 & Very Interested & 2 \\
used as posting place. & & & \\
\hline $\begin{array}{l}\text { Visits Office of the Sangguniang } \\
\text { Bayan to gain insights on new } \\
\text { legislation. }\end{array}$ & 3.68 & Interested & 4 \\
\hline $\begin{array}{l}\text { Access social media to have } \\
\text { updates on new policies in the } \\
\text { community. }\end{array}$ & 3.00 & Moderately & 5 \\
\hline $\begin{array}{l}\text { Interest to be informed of new } \\
\text { legislation by the Sangguniang } \\
\text { Bayan. }\end{array}$ & 4.85 & Very Interested & 1 \\
\hline \begin{tabular}{l} 
Composite Mean \\
\hline
\end{tabular}
\end{tabular}

The data in Table 6 is indicative of the level of interest of punong barangays towards ordinance information. Those ordinal scales measured the frequency levels concerning the level of interest of respondents of being informed on various legislations. The analyses show a positive attitude (3.95) among the respondents and are willing to be informed anent local ordinances. In contrary, the Secretary to the Sangguniang Bayan stated that some punong barangays seldom attend public consultations and rarely or not at all visit their office to gain updates and to clarify provisions on approved ordinances. According to him, it only shows that they do not read it even if they were continuously being provided with copies.

One of the process indicators of local governance includes the procedures adopted and actions undertaken in order to achieve the results (United Nations Development Programme (UNDP) Oslo Governance Center, 2008). Thus, for the local government to function, in this case the barangay, it should have functioning and quality administrative systems, planning and policy-making procedures and implementation mechanisms. Based on the results and the researchers' observation, the punong barangays are only interested in being informed of new ordinance, but they show less interest in reading it and participating in public consultations and gaining updates from Sangguniang Bayan. These obviously show the negative interest of the barangay officials to effective local governance. It also infers that, no matter how effective the information dissemination of ordinances are, from municipal to barangay, the attitude and interest of the barangay officials receiving the information will affect the dissemination of the policies to the public. 


\subsection{Awareness of Punong Barangays Regarding Peace and Order Ordinances}

Table 7. Awareness of Punong Barangays on Peace and Order Ordinances

\begin{tabular}{l|c|c|c}
\hline Peace and Order Ordinances & WM & VI & RANK \\
\hline $\begin{array}{l}\text { Prescribing regulation on } \\
\text { certain movements of minors } \\
\text { during the prescribed hours } \\
\text { (Curfew ordinance) }\end{array}$ & 3.88 & Less Aware & 5 \\
\hline $\begin{array}{l}\text { Regulating the sale, } \\
\text { distribution, possession, and } \\
\text { use of firecrackers }\end{array}$ & 2.47 & Highly Aware & 2 \\
\hline $\begin{array}{l}\text { Anti-noise pollution } \\
\text { ordinance }\end{array}$ & 3.50 & Aware & 4 \\
\hline $\begin{array}{l}\text { Prohibiting illegal motor } \\
\text { vehicle and motorcycle racing }\end{array}$ & 3.18 & Aware & 3 \\
\hline $\begin{array}{l}\text { Violence against women } \\
\text { VAW) desk in all barangays }\end{array}$ & 3.38 & Aware & \\
\hline Composite Mean & 3.28 & & \\
\hline
\end{tabular}

Concerning the level of awareness (Table 7), all of the respondents are aware of the peace and order ordinances. The overall assessment of the respondents on the level of awareness was 3.28 and verbally interpreted Aware. The Curfew ordinance (3.88) is well-known by the punong barangays which ranked first followed by the Anti-noise pollution ordinance with a weighted mean of 3.50. The Firecracker regulation ordinance has the lowest level of awareness. This may be because it is not yet applicable during the time of its enactment. The punong barangays are expected to be a hundred percent highly aware of all the ordinances, yet there are some who are still not familiar to such. This may be because even if they are being furnished by copies of ordinances, they do not give the proper attention to those documents.

The barangay is the smallest political unit in the Philippines and the nearest to the people in the communities. It functions as the primary planning and implementing unit of government programs, projects and activities (Gabriel \& Manuzon, 2016; Cuya-Antonio \& Antonio, 2017). And the organizational effectiveness of the barangays depends on the performance of their functions as mandated by law (Cuya-Antonio \& Antonio, 2017). Thus, complacency and ignorance of the barangay officials to national and local policies is synonymous to its non-performance of its functions and ineffectiveness in governance.

\section{Conclusions}

The dissemination of information about local ordinances commences at the time of crafting. Starting early usually increases the impact of dissemination. Providing people with notice of what is planned can strengthen partnerships and networks (Harmsworth \& Turpin, 2000). Some factors must be considered to institute strategies on dissemination which could have a significant connection on the awareness of the public. 
Based on the results, the socio-demographic characteristics of the respondents should be taken into consideration because understanding your audience is necessary for communicating effectively. In the conduct of this study, the following were revealed:

1. Gender - Majority of the respondents are male (79.41\%).

2. Age - Majority of the punong barangays (79.41\%) in the municipality are at their middle age from 18 to 59 years of age.

3. Education - The study reveals that most of the respondents have either finished high school $(35.29 \%)$ or have attended/graduated college $(64.71 \%)$.

4. Barangay Land Classification of Respondents - The majority of the respondents $(67.65 \%)$ are residing in lowland barangays and have accessible transportation to the town hall thus having easy access to information.

Posting of ordinances by the Sangguniang Bayan was proven to be an effective method of dissemination based on the study. However, it was suggested that it should not be limited to that. It has been observed that those respondents who are unaware of the ordinances are from upland barangays far from the town proper.

Other factors and medium involved also play significant roles in the process. The study shows that the level of interest of punong barangays towards obtaining information is positive. However, results of the interview with the Sangguniang Bayan Secretary, found out that respondent-punong barangays rarely attend public consultations and visit their office to gain updates on new legislation.

The respondent-punong barangays perceived that they are aware of the peace and order ordinances. Others are less aware or not at all aware of particular ordinances. As implementers, they are expected to be utterly acquainted with this statute to function as mandated by law for effective governance. The awareness of the public relies on the effective information dissemination as well as the attitude and ways of the government officials in disseminating those policies.

\section{Recommendations}

Based on the outcome of the study, the level of awareness of the punong barangays on ordinances about peace and order is only above par. Specific action should be initiated to increase the level of awareness of the punong barangays regarding various measures being implemented.

In consideration of those above, the following recommendations are forwarded:

1. It is recommended that high ranking officials push for the stability of network connections within the municipality so that internet connections could be maximized in government service delivery. Social media account for every barangay government should be activated directly linked to the municipal account so that they could be updated on new enactment. It is also recommended that to stir up participation, a certain percentage of the fines for every apprehension be given to the barangay government and apprehender. 
2. Massive information and education drive must also be conducted mostly during barangay assemblies to inculcate in the minds of the constituents what are the different measures being implemented in the municipality.

3. Strong political will of the enforcers should be observed at all times. The attitude and interest of the information receiver are vital because even they are being furnished with copies but do not enforce the stated provisions, the efforts will be wasted. Support from the local chief executive is required especially regarding budget and manpower. There should be an active involvement not only of legislators but also the implementers and the populace.

\section{References}

Black, H. C. (1910). A law dictionary. Second Edition. West Publishing Co. Retrieved from https://ia902608.us.archive.org/16/items/BlacksLaw2dEd/A_Law_Dictionary.pdf, 590

Caldo, R. B. (2015, March). Assessment of competency measures of barangay council in San Jose, Sto. Tomas, Batangas. DLSU Research Congress 2015.

Capeless, D. F. (n.d.). Crime awareness and prevention. Retrieved March 19, 2018, from http://www.mass.gov/berkshireda/crime-awareness-and-prevention/

Cartwell II, D. D., Orr, C. L., \& Kelemen, D. B. (2006). Effectively disseminating information to limited-scale landowners in the urban/rural interface. Journal of Extension, Retrieved from http://www/joe.org/joe/2006february/a5.shtml/

Catedrilla, L. C. (2000). Extension in community-based coastal resource management of Batan Bay, Aklan, Philippines. Danyag, 5(2), 217-236

Catedrilla, L. C., Serofia, G. D., Espectato, L. N., \& Jimenez, C. N. (2010, January). Factors affecting effective the dissemination of fisheries laws in District 1, Iloilo Province, Philippines. Danyag: Journal of Humanities and Social Sciences, 15, 81-96.

Comprehensive Land Use Plan of the Municipality of Maria Aurora, Aurora (2017).

Converse, P. E. (1972). Change in the American Electorate. In The Human Meaning of Social Change, ed. Angus Campbell and Philip E. Converse. New York, NY: Russell Sage Foundation pp. 263-337.

Croke, K., Grossman, G., Larreguy, H. A., \& Marshall, J. (2014). The Effect Of Education On Political Participation In Electoral Authoritarian Regimes: Evidence From Zimbabwe 1-59.

Cuya-Antonio, O. C., \& Antonio, H. D. P. (2017). Effectiveness of the Barangay Disaster Risk Reduction and Management Committees (BDRRMCs) in Flood-Prone Barangays in Cabanatuan City, Philippines. Open Access Library Journal, 4, e3635. https://doi.org/10.4236/oalib.1103635

Executive Order No. 366 (1996). Further amending Executive Order No. 309, S. Of 1987, entitled "Reorganizing the Peace and Order Council", as ammended by Executive Order No. 317, S. Of 1988, Executive Order No. 320, S. Of 1988 and Executive Order No. 20, S. Of 1992 and organizing the barangay peace and order committees as the implementing area of the City/Minicipal peace and order council at the barangay level. 


\section{Mll Macrothink}

Journal of Public Administration and Governance

ISSN 2161-7104

2018, Vol. 8, No. 4

Gabriel, A. G. (2017). Transparency and accountability in local government: levels of commitment of municipal councillors in Bongabon in the Philippines. Asia Pacific Journal of Public Administration, 39(3), 217-223. https://doi.org/10.1080/23276665.2017.1368902

Gabriel, A. G., \& Manuzon, E. D. P. (2016). Management, Decision Making Styles and Training Preferences of Barangay Officials in Nueva Ecija Philippines. North Asian International Journal of Social Sciences and Humanities, 2, 93-110.

Gatab, M. B. (2008, April). Communication strategies in the formulation and dissemination of ordinances in the Municipality of Bakun, Benguet. Benguet State University Digital Library.

Harmsworth, S., \& Turpin, S. (2000, July). Creating an effective dissemination strategy, An expanded interactive workbook for educational development projects. ignorantia legis neminem excusat (n.d.). In Wikipedia. Retrieved March 21, 2018, from https://en.wikipedia.org/wiki/Ignorantia_juris_non_excusat

Inter-Parliamentary Union. (1999). Participation of Women in Political Life. New York: IPU [Online] Available at: http://www.ipu.org/PDF/publications/ womenplus5_en.pdf

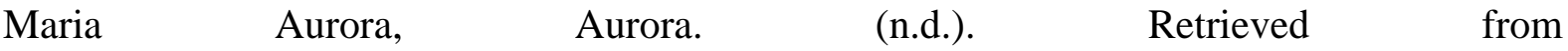
https://en.wikipedia.org/wiki/Maria_Aurora,_Aurora

Martin, M. (Ed.). (2005). Local and regional government information. How to find it, how to use it. Greenwood Press.

Mediocre, D. (2011). All Women Shortlists: A Route To equality? [Online] Dreaming Genius [Online]

Available

from

http://www.dreaminggenius.com/2011/06/all-women-shortlists-route-to-equality.html

Mele, C., Pels, J., \& Polese, F. (2010). A brief review of systems theories and their managerial applications. Retrieved from https://pubsonline.informs.org/doi/pdf/10.1287/serv.2.1_2.126

Municipal Ordinance No. 20 series 2015 of Maria Aurora, Aurora - An ordinance establishing a Public Information System through airing of the Programs, projects and activities and undertakings of the Municipal Government of Maria Aurora on a Radio Program and providing funds thereof.

Newstrom, J. W. (2011). Organizational behavior, Thirteenth edition. McGraw-Hill

Opyd, D. (2014). Men and Media: Friends or Enemy of Women Parliamentarians? Under-Representation of Women in Politics. Athens Journal of Social Sciences, January 2014, 1(1), 35-46. https://doi.org/10.30958/ajss.1-1-3

Philippine Statistics Authority Census of Population (2016).

Republic Act No. 6644 (1987). An act reducing the minimum age of the different elective local officials by ammending Section 42 of Batas Pambansa Bilang 337, otherwise known as the Local Government Code. 
Republic Act No. 7160 or the Local Government Code of 1991.

Rogers, E. M. (1983). The diffusion of innovations, 2nd edition, New York: Free Press

Shaifuddin, N., Ahmad, M., \& Haliza Wan Mokhtar, W. (2011). Rural youth's perceptions of information sources and rural library services. Library Philosophy and Practice (e-journal.655. Retrieved from https://digitalcommons.unl.edu/cgi/viewcontent.cgi?article $=1729 \&$ context $=$ libphilprac

United Nations International Children's Emergency Fund. (2007). The State of the World's Children 2007. Women and Children. The Double Dividend of Gender Equality [Online] Available at: http://www. unicef.org/sowc07/docs/sowc07.pdf

Walker, E. (2017, April 13). Enforce idling ordinances by making them known. Retrieved March 19, 2018, from The Municipal Website: http://www.themunicipal.com/2017/04/enforce-idling-ordinances-by-making-them-known/

\section{Copyright Disclaimer}

Copyright for this article is retained by the author(s), with first publication rights granted to the journal.

This is an open-access article distributed under the terms and conditions of the Creative Commons Attribution license (http://creativecommons.org/licenses/by/4.0/). 